$\xi=$

\title{
Comparative study of biogas production from animal wastes by anaerobic digestion
}

\author{
Soom, S. T *, Adeyinka, A. Orsar, J. S., Ishuwa, M. N \\ Department of Biological Sciences, University of Mkar, Benue-Nigeria \\ *Corresponding author E-mail:soomsolomon@yahoo.com
}

\begin{abstract}
This study compares biogas production from cattle dung, piggery faeces and poultry wastes under different environmental conditions by anaerobic digestion as a means of managing municipal solid wastes and was conducted in the Department of Biological Sciences, Benue State University, Makurdi from 1st August, 2011 to 13th December, 2011. A $6 \mathrm{Kg}$ of each of waste was mixed with four litres of water and loaded into three locally constructed digesters. The biogas produced was measured using water displacement method after every 5 days. The result indicated that piggery feaces gave the highest yield of biogas $(1.07 \mathrm{~L} / \mathrm{kg})$, followed by cattle dung $(0.71 \mathrm{~L} / \mathrm{kg})$, with poultry wastes the least $(0.42 \mathrm{~L} / \mathrm{kg})$ all under direct sunlight. This study shows that piggery droppings are the best substrate for biogas production and the best yield result when the process is carried out under direct sunlight. However, statistical analysis showed no significant difference in the biogas yield of these feed stocks at $5 \%$ level of significance. Anaerobic digestion is recommended to be explored as an environmentally friendly technology for organic waste management.
\end{abstract}

Keywords: Biogas; Anaerobic Digestion; Environmental Conditions; Piggery Faeces; Poultry Wastes.

\section{Introduction}

Environmental degradation resulting from natural and anthropogenic activities has taken a centre stage in global discourse. Waste generation by animals is rapidly increasing and creating enormous waste disposal and management problems. The main cause has been traced to population growth and urbanization. Several studies have shown that if the wastes are not properly managed, they will grow to such a level that will prevent human beings from carrying out their daily activities and have adverse effects on human live (Adedib 1985, Doelle 2001, Monnet 2003, Ubwa, 2013). Solid waste management and treatment methods include sanitary landfill, incineration, pyrolysis, open dumping and burning, ocean dumping and composting (Nsi 2007). Each of these methods has its peculiar problems. In many areas the lands for disposal of wastes are no longer available. Waste accumulations in landfills are also the source of odorous emissions to the atmosphere (Verma 2002). In other cases like incineration and pyrolysis, air pollution problems are predominant and initial investment are also very high (Xuereb 1997). Government and industries are constantly searching for technologies that will allow for more efficient and cost-effective waste treatment/management. One technology that can successfully treat the organic fraction of wastes is anaerobic digestion; it has the advantage of producing energy, yielding high quality fertilizer and also preventing transmission of diseases (Xuereb 1997).

Anaerobic digestion is a controlled degradation of organic wastes by microorganism in the absence of oxygen. The digestion is carried out using an airtight digester and other equipment used for waste pre-treatment and gas retrieval. The process generates a product called "biogas" that is primarily composed of methane, carbon-dioxide and compost products suitable as soil conditioners on farmlands (Koberle 2006).
The final effluent can be used as fertilizer on farmlands and sometimes as animal food additives. Harnessed biogas can either be processed and sold directly or used to generate energy which can then be sold. Anaerobic digestion also produces savings by avoiding cost of synthetic fertilizers, soil conditioners and energy from other sources (Abbasi 1990). Most of the biogas researches in Nigeria use animal wastes as feedstock (Fernando et al 1986, Machido 1996). A few have explored other feedstock such as water hyacinth [12], aquatic weeds (Abbasi 1990) and leaf liter (Ubwa et al 2013, Akinbami et al 2000). Approximately $70 \%$ of Nigeria's population lives in areas where no formal waste management systems are in place. A recent study assessed Nigeria's biogas potentials (minimum value) from solid wastes and livestock excrements. It revealed that in 1999, Nigeria's biogas potentials represented a total of $1.382 \times 10^{9} \mathrm{~m}^{3}$ of biogas/year or an annual equivalent of 4.81 million barrels of crude oil (Akinbami et al 2000). In the present study biogas yield from cattle dung, piggery faeces and poultry wastes under different environmental conditions were studied.

\section{Materials and methods}

\subsection{Waste collection and slurry preparation}

Fresh wastes of cattle, pig and poultry were collected from Gboko Abattoir, Aende piggery farm Gboko and Vakaa poultry farm, Gboko respectively from Benue State, Nigeria. These waste samples were stored in black sealed polythene bags to conserve the moisture and taken to the laboratory at University of Mkar, Mkar, Gboko, Nigeria. The wastes were mixed with water in a ratio of 1.5:1 to get the desired total solid concentration. The slurry was mixed thoroughly to ensure that any air trapped in the waste was removed before the slurry was introduced into the digester tank. 
This was to ensure the elimination of oxygen from the slurry and enhance its anaerobic digestibility when eventually introduced into the digester (Engler, 2010). The prepared slurry was introduced into the digester by pouring it through a plastic funnel.

\subsection{Experimental procedure}

A $6 \mathrm{~kg}$ of each waste was weighed, and then mixed thoroughly with $4 \mathrm{~L}$ of water for optimum gas production. This was then loaded to about three-quarter of the digester volume. The digester inlet and outlet openings were tightly sealed to exclude oxygen. The digester containing feedstock of cattle dung, poultry droppings and piggery waste were labeled as digester 1,2 , and 3 respectively. The digesters were subjected to periodic shaking after every six hours to ensure thorough mixing while maintaining intimate contact between the microorganisms and feedstock and to enhance complete digestion of feedstock (Ojolo 2007). The volume of biogas yield was measured using a measuring cylinder and recorded in five days interval. The first, second and third setups were monitored for 45 days each under different environmental conditions (under direct sunlight, under-shade and indoor) from $1^{\text {st }}$ August, 2011 to $13^{\text {th }}$ December, 2011. During this period, daily ambient temperature varied from $29{ }^{\circ} \mathrm{C}$ to $38{ }^{\circ} \mathrm{C}$. Analysis of variance (ANOVA) was carried out based on multiple statuses of the variables to be compared.
Water displacement method was used to measure the quantity of biogas produced (Ojolo 2007). To every digester, two containers were used. The container (A) was connected via an airtight tube directly to the $15 \mathrm{~L}$ capacity digester. The biogas produced moved under the digester pressure through the tube into the water-filled container (A). The water-filled container has a tube leading from its interior to the water collection container (B) which receives the displaced water. The water displaced was measured using a measuring cylinder. The volume of biogas produced in a given time was equal to the volume of water displaced within the period (Yadvikan 2007, Itodo 2007). Biogas yield was measured on the $5^{\text {th }}, 10^{\text {th }} 15^{\text {th }}, 20^{\text {th }}, 25^{\text {th }}, 30^{\text {th }}, 35^{\text {th }}, 40^{\text {th }}$ and $45^{\text {th }}$ day of digestion from each waste type investigated. Ten measurements were taken within 45 days and triplicate reading for three different animal wastes under three environmental conditions (under direct sunlight, under-shade and indoor) were noted.

\section{Results and discussion}

\subsection{Results}

The result of biogas production from cattle dung, piggery feaces, and poultry droppings at different environmental conditions are presented in tables 1 to 3 .

\subsection{Production of biogas from animal wastes}

Table 1: Biogas Yield (L/Kg) from Cattle Dung

\begin{tabular}{|c|c|c|c|}
\hline \multirow{2}{*}{$\begin{array}{l}\text { Detention Time } \\
\text { (in days) }\end{array}$} & \multicolumn{3}{|c|}{ Environmental Conditions } \\
\hline & Under direct sunlight & Under-shade & Indoor \\
\hline 0 & - & - & - \\
\hline 5 & 0.16 & 0.15 & 0.154 \\
\hline 10 & 0.20 & 0.19 & 0.22 \\
\hline 15 & 0.30 & 0.33 & 0.36 \\
\hline 20 & 0.76 & 0.63 & 0.65 \\
\hline 25 & 0.69 & 0.69 & 0.73 \\
\hline 35 & 0.52 & 0.59 & 0.52 \\
\hline 40 & 0.42 & 0.48 & 0.44 \\
\hline 45 & 0.21 & 0.33 & 0.32 \\
\hline
\end{tabular}

Table 2: Biogas Yield (L/Kg) from Piggery Feaces

\begin{tabular}{llll}
\hline $\begin{array}{l}\text { Detention Time } \\
\text { (in days) }\end{array}$ & Environmental Conditions & \\
& Under direct sunlight & Under-shade & Indoor \\
\hline 0 & - & - & 0.12 \\
5 & 0.14 & 0.07 & 0.12 \\
10 & 0.09 & 0.04 & 0.07 \\
15 & 0.05 & 0.02 & 0.05 \\
20 & 0.03 & 0.16 & 0.02 \\
25 & 0.22 & 0.27 & 0.19 \\
30 & 0.30 & 0.99 & 0.28 \\
35 & 1.02 & 1.08 & 0.99 \\
40 & 1.15 & 0.99 & 1.10 \\
45 & 1.14 & & 1.09 \\
\hline
\end{tabular}

Table 3: Biogas Yield ( $\mathrm{L} / \mathrm{Kg}$ ) from Poultry Droppings

\begin{tabular}{|c|c|c|c|}
\hline Detention Time (in days) & $\begin{array}{l}\text { Environmental Conditions } \\
\text { Under direct sunlight }\end{array}$ & Under-shade & Indoor \\
\hline 0 & - & - & - \\
\hline 5 & 0.04 & - & 0.02 \\
\hline 10 & 0.37 & 0.03 & 0.04 \\
\hline 15 & 0.66 & 0.32 & 0.09 \\
\hline 20 & 0.37 & 0.48 & 0.19 \\
\hline 25 & 0.26 & 0.50 & 0.44 \\
\hline 30 & 0.19 & 0.40 & 0.67 \\
\hline 40 & 0.09 & 0.17 & 0.34 \\
\hline 45 & 0.03 & 0.17 & 0.03 \\
\hline
\end{tabular}




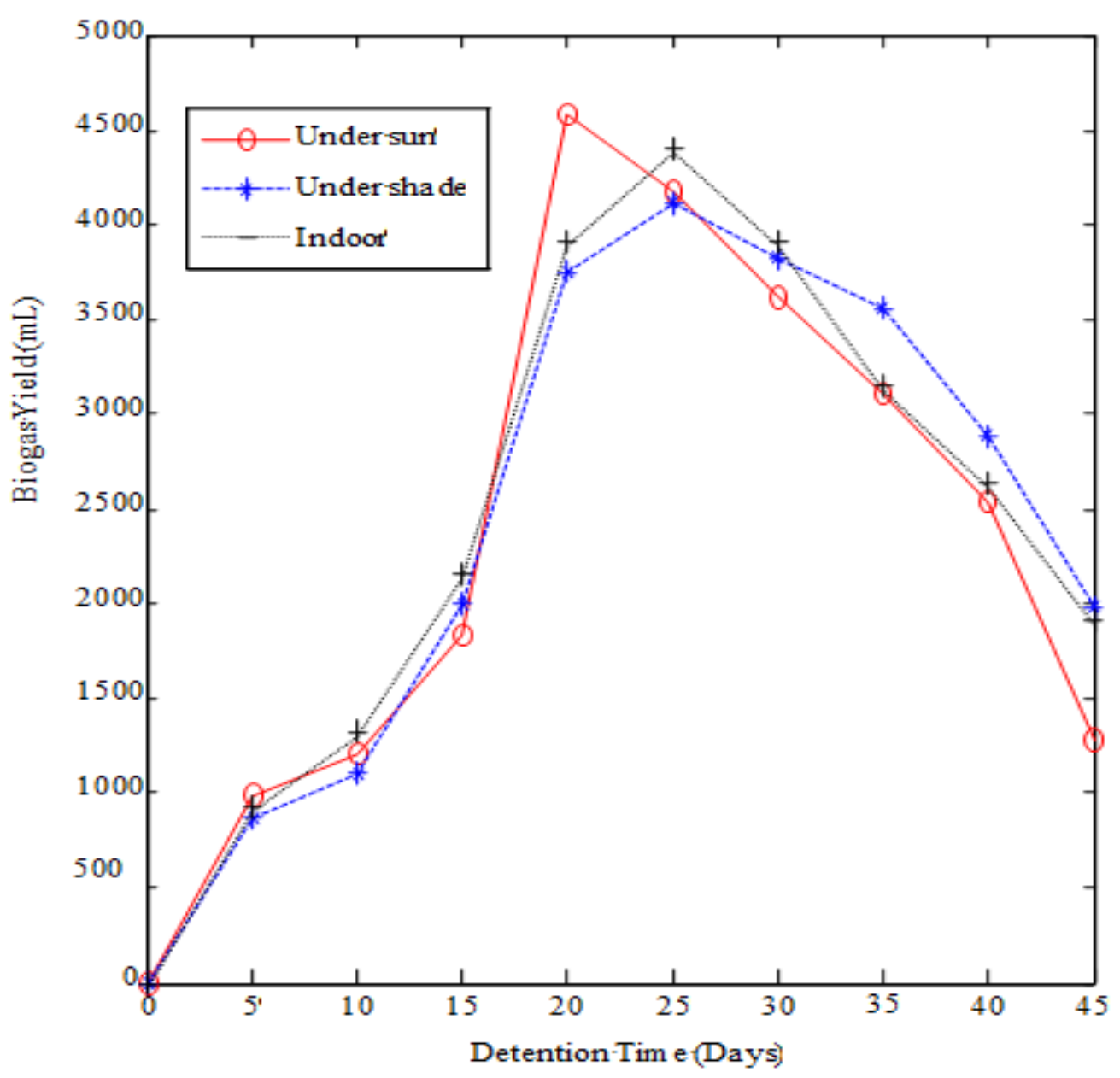

Fig. 1: Biogas Yield from Cattle Dung.

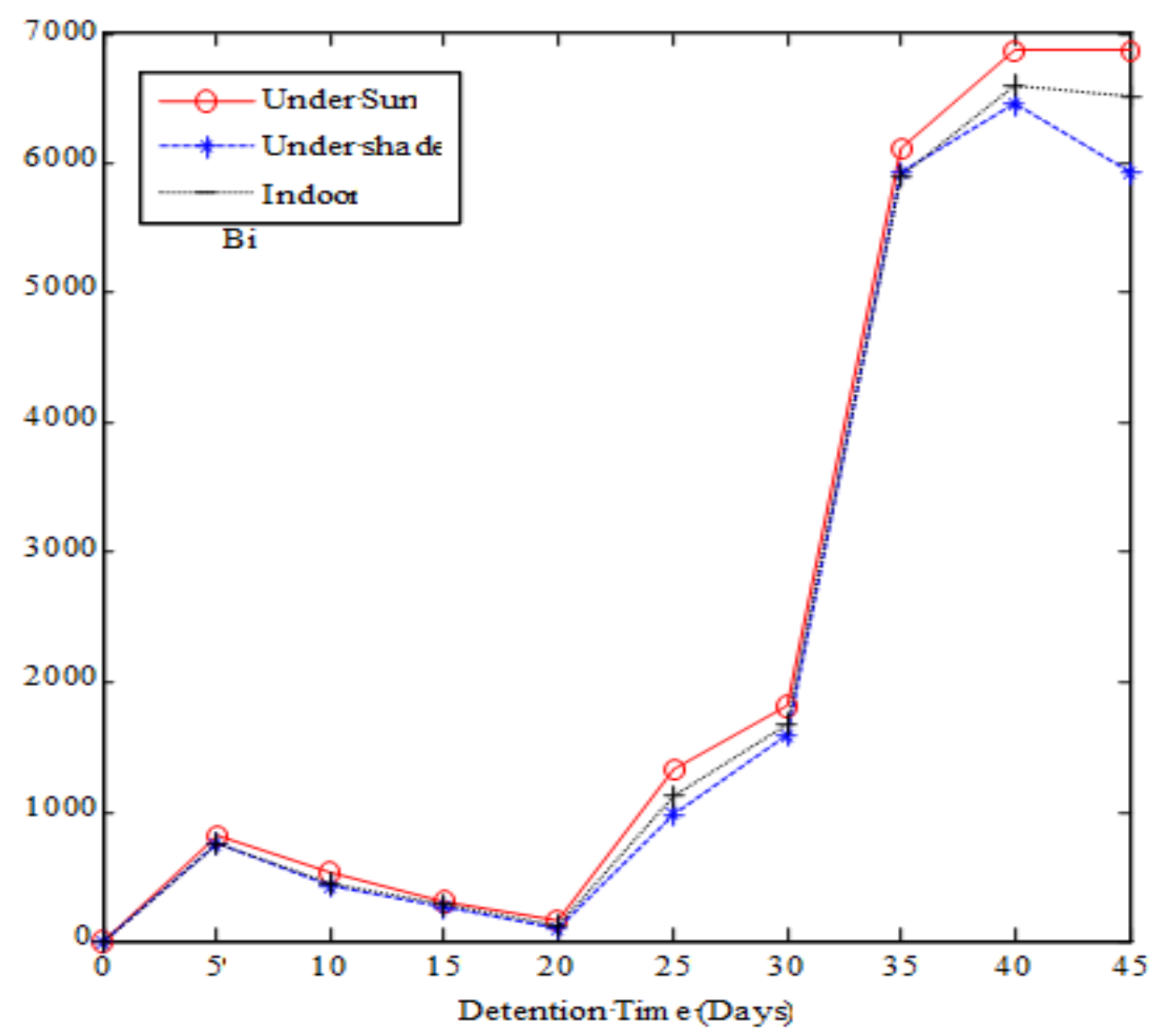

Fig. 2:Biogas Yield from Piggery Faeces. 


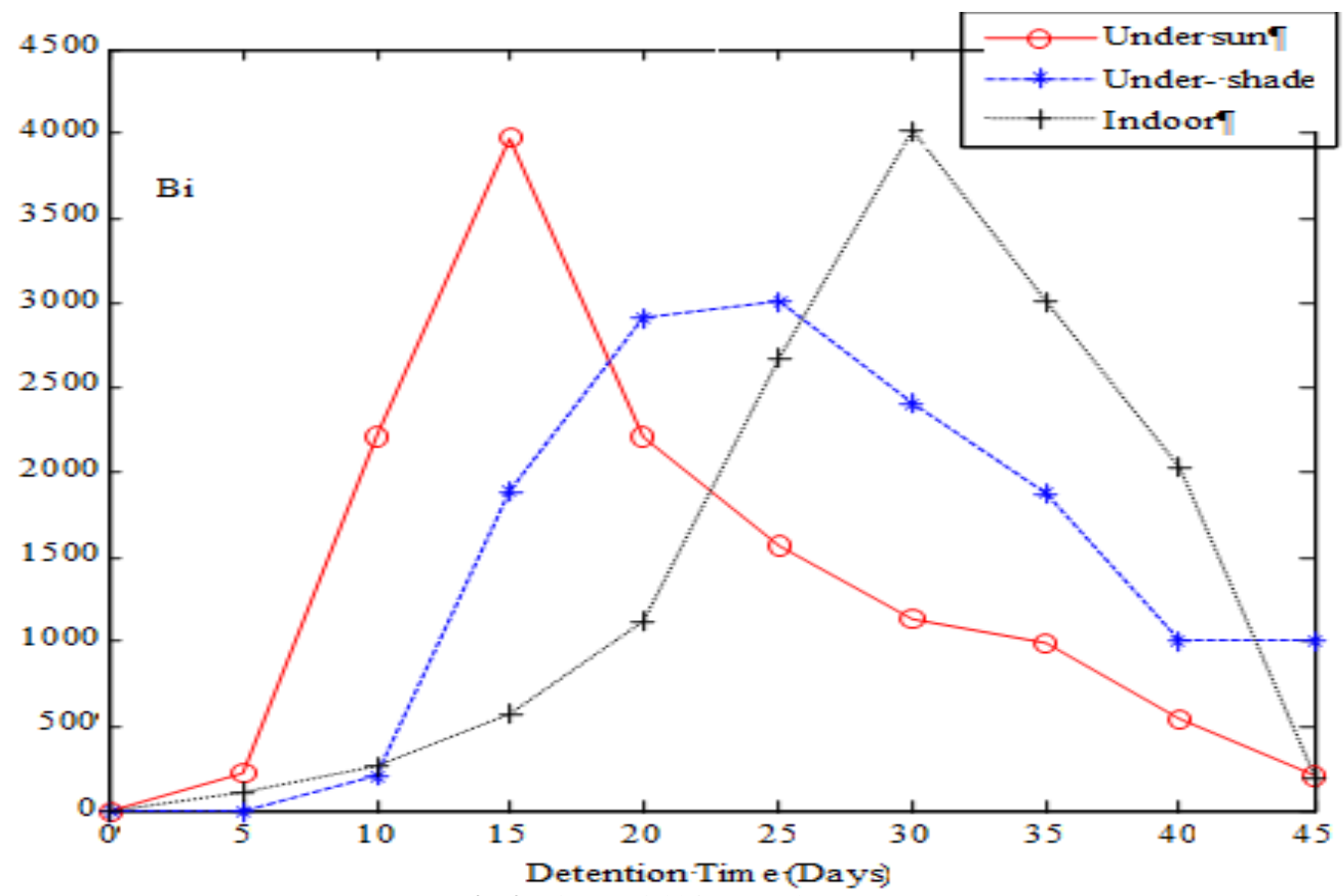

Fig. 3: Biogas Yield from Poultry Waste.

The quantity of biogas produced from the cattle dung, over a period of 45 days at different environmental conditions (indoor under direct sunlight, under shade) is presented in table 1 . It was observed that biogas production started in all the digesters two days after loading. It was also observed that gas production continued gradually on subsequent days then suddenly peaked on $20^{\text {th }}$ day with $0.76 \mathrm{~L} / \mathrm{kg}$ under direct sunlight, Production reached the peak on the $25^{\text {th }}$ day, producing $0.69 \mathrm{~L} / \mathrm{kg}$ and $0.80 \mathrm{~L} / \mathrm{kg}$ under shade and indoor respectively. The yield then decreased slightly in all the environmental conditions. On the $45^{\text {th }}$ day, the gas production was $0.21 \mathrm{~L} / \mathrm{kg}, 0.33 \mathrm{~L} / \mathrm{kg}$, and $0.32 \mathrm{~L} / \mathrm{kg}$ under direct sunlight, shade, and indoor respectively.

Production from piggery faeces, over a period of 45 days at different environmental conditions (indoor, under direct sunlight, under shade) is summarized in table 2. It was observed that gas production started on the $3^{\text {rd }}$ day after loading in all the digesters, and increased in two days. On the $5^{\text {th }}$ day biogas yield was $0.14 \mathrm{~L} / \mathrm{kg}$, $0.12 \mathrm{~L} / \mathrm{kg}$ and $0.12 \mathrm{~L} / \mathrm{kg}$ under direct sunlight, under shade and indoor respectively. Biogas yield decreases gradually until the $20^{\text {th }}$ day at which production was as low as $0.019 \mathrm{~L} / \mathrm{kg}, 0.017 \mathrm{~L} / \mathrm{kg}$, and $0.019 \mathrm{~L} / \mathrm{kg}$ under direct sunlight, under shed, and indoor respectively. From the $20^{\text {th }}-30^{\text {th }}$ day, there was gradual increase again. Between $30^{\text {th }}$ and $35^{\text {th }}$ day, there was a sharp increase in gas yield. This peaked on the $40^{\text {th }}$ day as follows: $1.15 \mathrm{~L} / \mathrm{kg}, 1.08 \mathrm{~L} / \mathrm{kg}$ and $1.10 \mathrm{~L} / \mathrm{kg}$ under direct sunlight, under shade, and indoor respectively. The decrease in yield was observed to be gradual.

Production of biogas under direct sunlight and indoor conditions started on the $4^{\text {th }}$ day and increased gradually with a peak on the $15^{\text {th }}$ day with $0.66 \mathrm{~L} / \mathrm{kg}$ of gas under direct sunlight and a peak on the $30^{\text {th }}$ day with $0.66 \mathrm{~L} / \mathrm{kg}$ under indoor (table 3 ). Under shade, production started on the $10^{\text {th }}$ day and increased sharply to a peak on the $25^{\text {th }}$ day with a production of $0.50 \mathrm{~L} / \mathrm{kg}$.

These results shows that, piggery feaces, yielded highest biogas volume $(1.07 \mathrm{~L} / \mathrm{kg})$ followed by cattle dung $(0.71 \mathrm{~L} / \mathrm{kg})$ and poultry wastes produced the least volume of $0.42 \mathrm{~L} / \mathrm{kg}$.

\subsection{Discussion}

In this study, the gas production under direct sunlight was higher than under shade and indoor. This could be attributed to the fact that, temperatures under direct sunlight are higher than other conditions considered in this study. This observation is consistent with the findings that decomposition or conversion of organic matter by anaerobes is more rapid at mesophylic and thermophylic conditions ((Itodo 2007)).
The growth pattern of bacteria under batch conditions showed a phase of increasing growth rate, a stationary phase for some time then decreasing growth rate (Gaffa 2005) and it was observed that the more the population of bacteria, the more the gas yields $(\mathrm{Hu}-$ manik 2007). Detention time affect both bacteria population of the slurry and biogas yield (Keareney et al 1993). Bacteria population increases at the beginning but reaches a maximum point and as the detention time continues to increase, the population decreases.

In a similar work carried out, the viable numbers of species of microbes were reduced in population during anaerobic digestion after 30 days (Itodo 2007).

Biogas yield also followed the same pattern; that is increase in yield at the beginning and decrease with increase in detention time after reaching a maximum point. The pattern is the same because microbes are responsible for the biogas yield (Boone 2006).

At every point throughout the 45 days of the experiment, gas yield remained higher under direct sunlight than under shade and indoor conditions. This is not synonymous to the observation made on biogas production from cattle dung. The decrease in gas production from Piggery droppings from the $5^{\text {th }}$ to $20^{\text {th }}$ day could be traced to the composition of the pig's food (oil, fats, meat etc). Pigs are omnivores as such some of the ingredients in their food could be inhibitors to bacteria growth and consequently biogas production (Ojolo 2007). These anaerobes took some days to resist after which production shoot up sharply.

In all the three feedstock used, production under-shade is always lower than the rest. This is attributed to the fact that hot environments expedite decomposition and promotes efficiency of gas production.

A difference exists between poultry droppings and wastes. Wastes are not only droppings and can contain inhibitors to bacteria growth. It can be observed that piggery dropping and poultry wastes contain wastes that are inhibitory to gas production. However, it must be born in mind that the digestive system of the animal will influence the amount of organic matter in its faeces (Ojolo 2007). This is also similar to results in (Guruswamy 2003). With a good stirring mechanism, the result would have been better than what it is.A good stirring mechanism, mixing or shaking the digester is very important as it prevents scum formation and avoids temperature gradients within the digester (Ojolo 2007).

The result of the ANOVA test for the equality of means between the different conditions under which piggery biogas yield was recorded showed a probability value of 0.9832 ( $p>0.05)$ indicating no significant difference between the piggery biogas yield obtained from the different conditions. A similar trend was in each 
case observed for biogas yield of poultry dropping and cattle dung under the different environmental conditions subjected. Each had a probability value 0.9858 and $0.9870(\mathrm{p}>0.05)$ indicating the absence of significant difference for biogas yield of the various feedstock under sunlight, in shades and indoors.

The ANOVA result on the biogas yield under sunlight revealed that, there was no significant difference between the yields from piggery, poultry dropping and cattle dung. This is evidenced by the probability value of 0.3850 which is greater than the alpha level of 0.05 (5\% level of significance). This similar trend was observed for the biogas yield of piggery, poultry and cattle dung obtained under shades and indoors with p-values of 0.4397 and 0.4498 being greater than the alpha level of 0.05 indicative of no significant difference.

\section{Conclusion}

This study was aimed at making a comparative study of biogas production from animal wastes and determining the waste type that gives the highest yield of biogas under certain environmental conditions. The results of the study revealed that piggery faeces produced the highest volume of biogas and was collected between 15-40 days of the detention time.

The environmental condition that was more appropriate and efficient for the production of biogas was under direct sunlight. This revealed that production of biogas can be done better under direct sunlight digestion. Anaerobic digestion is good for management of animal waste and reduction of toxic pathogens in animal wastes.

The technology is environmentally friendly because the biogas which is a methane rich gas burns completely without emitting greenhouse gases. The effluent and waste water could be free of toxic pathogens.

\section{Competing interests}

Authors have declared that no competing interests exist.

\section{References}

[1] Adedib, A. A., A comparative analysis of solid waste composition and generation in two cities of developing nations. The Environmentalist, $\quad$ (1985), $\quad 5(2): \quad 123$ 128.http://dx.doi.org/10.1007/BF02235981.

[2] Ubwa, S. T., Asemave, K., Oshido, B., Idoko, A., Preparation of biogas from plants and animal wastes. International Journal of Science and Technology, (2013), 2(6): 480-485

[3] Doelle, H. W., Biotechnology and Human Development in Developing Countries, ejbiotechnology.info, (2001), Retrieved 19.08.07.

[4] Monnet, F., An introduction to anaerobic digestion of organic wastes. A report on http: //www, remade. Com, (2003)

[5] Nsi, E.W., Basic Environmental Chemistry The Return Press Ltd Makurdi, (2007)

[6] Verma, S., Anaerobic Digestion of Biodegradable Organics in Municipal solid wastes.Unpublished M.Sc. Thesis, Department of Earth and Environmental Enggineering, Foundation school of Engineering, Colombia University, (2002).

[7] Xuereb, P., Biogas-Afuel produced from waste. Newsletter of Michigan Institute of Waste Management,(1997),1(1):1-3

[8] Koberle, E., Animal manure digestion systems in central Europe. In proceedings of the second biomass conference of the August 21-24 Portland, Oregon, national renewable Energy laboratory (NREL), (2006), 23:34

[9] Abbasi, S. A., Nipancy, P. C., Schaumbery, G. D., Bioenergy potential of eight common weeds, biological wastes, (1990)

[10] Fernando, C. E. C and Dangogo, S. M., investigation of parameters which affect the performance of biogas plant, Nigerian Journal of Solar Energy, (1986),5:147-148

[11] Machido, D. A., Zuru, A. A. and Akpan, E. E., Effects of some inorganic nuteientts on the performance of cow dung as substrate for biogas production. Nigerian Journal of Renewable Energy, (1996), 4(2), 34-37.
[12] Lucas, E. B. and Bamgboye, A. I., Anaerobic digestion of chopped water hyacinth. Nigerian Journal ofRrenewable Energy, (1998), 6(1):62-66

[13] Maishanu, S.M and Sambo, A. I., Biogas generation from leaf literal a preliminary investigation. Nigerian Journal of Solar Energy (1991), 10:138-144.

[14] Akinbami, J. F. K., Liori, M. O., Oyebisi, T. O., Akinwumi, I. O., Adeoti, O., Biogas energy use in Nigeria: current status, future prospect and policy implication renewable and sustainable. Energy Reviews, (2000), 5:95-112.

[15] Engler, C. R., Jordan, E. R., McFarland, M. J., Lacewell, R. D., Economics and Environmental Impact of Biogas Production as a Manure Management Strategy, (2010).

[16] Ojolo, S. J., OkeK S. A., Animasahun, B. K., Utilization of poultry, Cow and kitchen wastes for Biogas production: a comparative analysis. Iranian Journal of Environmental Health Science and Engineering (2007), vol. 4 No. 42007 pp 223-228.

[17] Yadvikan, T. R., Streekrisman, S. 1, Santosh, S., Kohli, K., Effect of Hadraulic Retention Time and Slurry Concentration on Biogas Production in Cattle Dung Based Anaerobic Bioreactions. Journal of Environmental Technology, (2007):,1479-487 x vol. 28 issue 4, p 433-442.

[18] Itodo, I. N., Agricultural Energy Technology Aboki Publishers, Makurdi, Abuja-Ibadan. (2007), Pp. 108.

[19] Gaffa, T. and Azoro, C., Bacteriology for Biologists, Caterers and Food Technologists Amana Printing and Advert. Ltd, Kaduna, (2005).

[20] Humanik, F., Anaerobic Digestion of Animal Manure, Epa. Gov. (2007), Retrieved 17.08.07

[21] Keareney, T. E., Larkin, M. Frost, J., Levett, P., Survival of pathogenic bacteria during mesophilic anaerobic digestion of animal waste. Journal of Applied Microbiology,(1993), 75:215-219. doi: 10.1111/j-1365-2672. 1993. tb 02768.x

[22] Boone, D. and Mah, R., Transitional bacteria in anaerobic digestion of biomass, (2006), Retrieved 19.08.07.

[23] Guruswamy, T., kannan, N. and Kumar, V., Design, development and evaluation of biogas selected biomaterials as feedstock. IIE Journal, (2003), 84:1-65.

\section{Appendix I}

Piggery Biogas Yield under Different Conditions

Test for Equality of Means Between

Series

Date: 12/23/14Time: 17:04

Sample: 110

Included observations: 10

Method

df Value Probability

Anova F-test

$(2,27) \quad 0.0169730 .9832$

Welch F-test*

(2,

0.0162850 .9839

*Test allows for unequal cell variances

Analysis of Variance

\begin{tabular}{|c|c|c|}
\hline Source of Variation & df & $\begin{array}{l}\text { Sum of Mean Sq. } \\
\text { Sq. }\end{array}$ \\
\hline Between & 2 & 268697.3134348 .6 \\
\hline Within & 27 & $2.14 \mathrm{E}+087915302$. \\
\hline Total & 29 & $2.14 \mathrm{E}+08737868$ \\
\hline
\end{tabular}

Category Statistics

Variable Count

SUNLIGHT10 2470.070 2919.176923.1244

SHADES $\quad 10 \quad 2238.9302704 .083855 .1062$

INDOORS $10 \quad 2339.1602812 .873889 .5084$

$\begin{array}{lll}\text { All } & 30 & 2349.3872716 .373495 .9397\end{array}$




\section{Appendix II}

Poultry Dropping Biogas under Different Conditions

Test for Equality of Means Between

Series

Date: 12/23/14Time: 17:08

Sample: 110

Included observations: 10

Method

df Value Probability

Anova F-test

$(2,27) \quad 0.0145090 .9856$

Welch F-test*

$$
17.8883) 0.0143480 .9858
$$

*Test allows for unequal cell variances

Analysis of Variance

$\begin{array}{lll}\text { Source of Variation df } & \begin{array}{l}\text { Sum of } \\ \text { Sq. }\end{array} \\ \begin{array}{lll}\text { Between } & 2 & 48171.4624085 .73 \\ \text { Within } & 27 & 448206071660022 . \\ \text { Total } & 29 & 448687791547199 .\end{array}\end{array}$

Category Statistics

Variable Count Mean Std. Dev. of Mean

SUNLIGHT10 $\quad 1302.8601233 .208389 .9747$

$\begin{array}{lll}\text { SHADES } & 10 \quad 1380.6401182 .221373 .8513\end{array}$

INDOORS $10 \quad 1393.6001435 .833454 .0503$

All $\quad 30 \quad 1359.0331243 .865227 .0976$

\section{Appendix III}

Cattle Dung Biogas under Different Conditions

Test for Equality of Means Between

Series

Date: 12/23/14Time: 17:12

Sample: 110

Included observations: 10

Method

df Value Probability

Anova F-test

$(2,27) \quad 0.0131370 .9870$

Welch F-test*

(2, 0.9892$) 0.0122650 .9878$

*Test allows for unequal cell variances

Analysis of Variance

$\begin{array}{ll}\text { Source of Variation df } & \text { Sum of } \\ \text { Sq. }\end{array}$ Mean Sq.

Between $\quad 2 \quad 56110.9628055 .48$

Within $27 \quad 576618242135623$.

Total $\quad 29 \quad 577179351990274$.

Category Statistics

Variable Count Mean Std. Dev. Of

SUNLIGHT10 2331.2001512.833 478.3999

SHADES $10 \quad 2409.3301433 .289453 .2457$

INDOORS $10 \quad 2432.2201436 .624454 .3003$

All $\quad 30 \quad 2390.9171410 .771257 .5703$

\section{Appendix IV}

Biogas Yield under Sunlight

Test for Equality of Means Between Series

Date: 12/23/14Time: 17:27

Sample: 110

Included observations: 10

Method

df Value Probability

Anova F-test

$(2,27) \quad 0.9890260 .3850$

Welch F-test*

(2, 16.7387$) 1.6266000 .2262$

*Test allows for unequal cell variances

Analysis of Variance

$\begin{array}{lll}\begin{array}{l}\text { Source of Variation } \\ \text { df }\end{array} & \begin{array}{l}\text { Sum of } \\ \text { Sq. }\end{array} \\ \begin{array}{l}\text { Between } \\ \text { Within }\end{array} & 2 & 8130491.4065245 . \\ \text { Total } & 27 & 1.11 \mathrm{E}+084110351 . \\ & 29 & 1.19 \mathrm{E}+084107241 .\end{array}$

Category Statistics

Variable Count Mean Std. Err.

PIGGRY Dev. of Mean

$\begin{array}{llll}\text { PIGGERY } & 10 & 2470.0702919 .176923 .1244\end{array}$

$\begin{array}{lll}\text { POULTRY } & 10 & 1302.8601233 .208389 .9747\end{array}$

$\begin{array}{lrl}\text { DROPPING } & 10 & 1302.8601233 .208389 .9747\end{array}$

\begin{tabular}{lrl} 
All & 30 & 2034.7102026 .633370 .0108 \\
\hline
\end{tabular}

\section{Appendix V}

Biogas Yield under Shades

Test for Equality of Means Between Series

Date: 12/23/14Time: 17:31

Sample: 110

Included observations: 10

$\begin{array}{llll}\text { Method } & \text { df } & \text { Value } & \text { Probability } \\ \text { Anova F-test } & (2,27) & 0.847220 & 0.4397 \\ \text { Welch F-test* } & (2, & 1.589531 & 0.2332\end{array}$

*Test allows for unequal cell variances

Analysis of Variance

\begin{tabular}{|c|c|c|}
\hline Source of Variation & df & $\begin{array}{l}\text { Sum of Mean Sq. } \\
\text { Sq. }\end{array}$ \\
\hline Between & 2 & 6079670.3039835. \\
\hline Within & 27 & 968762753588010. \\
\hline Total & 29 & $1.03 \mathrm{E}+083550205$ \\
\hline
\end{tabular}

Category Statistics

Std. Err.

Variable Count Mean Std. Dev. of Mean

PIGGERY $\quad 10 \quad 2238.9302704 .083855 .1062$

$\begin{array}{lll}\text { POULTRY } & 10 & 1380.6401182 .221373 .8513\end{array}$

$\begin{array}{lll}\text { CATTLE } & 10 & 2409.3301433 .289453 .2457\end{array}$

\begin{tabular}{lll} 
DUNG & 10 & 2409.3301433 .289453 .2457 \\
All & 30 & 2009.6331884 .199344 .0061 \\
\hline
\end{tabular}




\section{Appendix VI}

Biogas Yield Indoors

Test for Equality of Means Between Series

Date: 12/23/14Time: 17:33

Sample: 110

Included observations: 10

Method df Value Probability

Anova F-test $\quad(2,27) \quad 0.8230250 .4498$

$\begin{array}{ll}\text { Welch F-test* } & (2, \\ & 17.0864)\end{array}$

*Test allows for unequal cell variances

Analysis of Variance

Source of Variation

df $\quad \begin{aligned} & \text { Sum of } \\ & \text { Sq. }\end{aligned}$

$\begin{array}{lll}\text { Between } & 2 & 6604918.3302459 .\end{array}$

Within $27 \quad 1.08 \mathrm{E}+084012586$.

Total $29 \quad 1.15 \mathrm{E}+083963611$

Category Statistics

Std. Err.

Variable Count Mean Std. Dev. of Mean

PIGGERY $\quad 10 \quad 2339.1602812 .873889 .5084$

$\begin{array}{lll}\text { POULTRY } & 10 & 1393.6001435 .833454 .0503\end{array}$

$\begin{array}{lll}\text { CATTLE } & 10 & 2432.2201436 .624454 .3003 \\ \text { DUNG } & \end{array}$

$\begin{array}{lll}\text { All } & 30 & 2054.9931990 .882363 .4837\end{array}$ 